\title{
A Review of the Macroeconomic Policy Frameworks adopted by the BRICS countries (2000-2015)
}

\author{
Themba Mbangata, Ogujiuba Kanayo \\ University of the Western Cape, South Africa \\ kannyog@gmail.com
}

\begin{abstract}
Recent development in the practice of macroeconomic policy has increased the importance of monetary and fiscal policy. Monetary policy within BRICS countries has shifted towards the setting of interest rates as the key monetary instrument, along with the adoption of inflation targets as key monetary policy objectives. It is well accepted that there is no one set of macroeconomic policies that guarantees sustained growth and development in the economy. However, the BRICS countries have been following a similar trend with regard to the exchange rate policy. This is shown by the fact that the BRICS countries have moved away from using a pegged exchange rate regime towards a managed floating exchange rate regime which is in contrast with the recommendations of the Washington Consensus. On the fiscal side, the BRICS countries agreed to spend only what is necessary in order to avoid the ballooning local government debt. Summarily, the BRICS countries have performed well economically and socially although there are still some room for improvement. However, there are still other BRICS members who have government debt that are well above half of their Gross Domestic Product. Alignment of policy regimes would strengthen the macroeconomic base of the BRICS. It is recommended that all BRICS members need prioritise inclusive governance that would checkmate social ills such as poverty, inequality and unemployment, while promoting social inclusion.
\end{abstract}

Keywords: BRICS, Macroeconomic policies, GDP, Economic Growth, Economic Development

\section{Introduction}

Currently, Brazil, Russia, India, China and South Africa are widely recognised as the world's most dynamically growing economies that have the potential to be the world's largest nations if everything goes as predicted by Golden Sachs experts in 2003. O'Neil (2001) argued that the growth potential of the BRICS countries can only be unleashed if certain macroeconomic policies are adopted in a well-coordinated manner that will promote economic growth and development. Although the BRICS nations are expected to be larger than the G6 countries in the next fifty years if Goldman (2003, P.05) predictions are correct, there are some known differences in macroeconomic policies that have been adopted by the different BRICS economies over the past few decades. Moreover, this could be due to the fact that each country has a unique population size with different cultural, financial and political background. These differences might provide an advantage for some BRICS nations in terms of growth and development potential and at the same time, provide a disadvantage for others. Nevertheless, Mtonga (2014) founded that the economic growth rates of the BRICS nations have slowed down over the past few years. This may be partly due to the 2008 global financial crisis as well as the problems or difficulties faced by each of these nations which may include the lack of coordination of macroeconomic policies in order to achieve sustained economic growth and development. However, , in the last couple of years, the BRIC economies have demonstrated swift economic progress so much so that the initial four comprising of Brazil, Russia India, and China are the four biggest economies outside of the OECD (Organization for Economic Co-operation and Development). These countries are the only developing countries with an annual Gross Domestic Profits of more than $\$ 1$ trillion.

The main characteristic that the BRICS have in common besides their large populations is their status as fastest growing economies and their shared idea that they are the fastest growing nations that should have a significant impact on global affairs. Their significant impact on global affairs is further supported by the fact that the BRICS countries combined, have approximately over 40 per cent of the world's human resources and more than 15 per cent of the world's Gross Domestic Product. Although there is no one set of macroeconomic policies that guarantees sustained economic development, there are certain recommended set of macroeconomic policies that BRICS and other developing countries have adopted in order to achieve economic growth and development. For instance, the Washington Consensus recommended policies have been adopted by various nations in one way or another including some of the BRICS countries. However, the countries that adopted the Washington Consensus recommended policies performed poorly due to the 2008 global financial crisis implying that they were exposed to global shocks. Macroeconomic policies are 
supposed to promote economic growth and development and at the same time, limit the exposure of a country to global shocks. This provides the underlying reasons as to why this mini-research article investigates whether or not the BRICS countries have been following the same trajectory with regard to macroeconomic policies for the past fifteen years. This will be done by examining the extent to which the monetary and fiscal policy frameworks of BRICS have differed.

\section{Literature Review}

The Washington Consensus which was coined by John Williams in the 90s and its Augmented version developed in 2003 proposed that (but not only), privatisation of public firms, decrease in budget deficit to non-inflationary levels, adherence to World Trade Organisation (WTO) disciplines, flexible labour markets, capital account opening, anti-corruption and redirecting government expenditure towards education and infrastructure as well as corporate governance may be a good starting point in the pursuit of growth and development (Herr and Priewe, 2005). As a result, many developing countries in Latin America and Africa started to adopt most of these macroeconomic policy recommendations. However, Herr and Priewe (2005) identified some disadvantages of the Washington consensus and argued that a relatively stable monetary system and a high quality currency with a sustainable balance of payment account are the key factors in achieving sustainable growth and development in a developing country. A stable exchange rate does not necessarily imply a fixed exchange rate but rather an exchange rate that does not vary too much especially due to international shocks (Herr, 2005). With regard to the downside of Washington Consensus, Ignoring the competitiveness of exchange rate markets by recommending a completely fixed or completely flexible exchange rate regime in a country was identified as one of the downside of the Washington consensus (Herr and Priewe, 2005, p.82).

In examining the impact of fiscal policy on growth, the potential reaction of the private sector needs to be considered. The Ricardian equivalence theory explains that an increase in government debt will lead to an equivalent opposite rise in private savings, since many economic participants will assume the need to repay higher taxes later in order to pay off the debt (Kraay, 2004). However, there is not much empirical evidence for Ricardian equivalence, so it remains mainly a textbook theory (Also see, Bernheim 1987). In fact, the actual observation is that government debt is rarely paid over. More usually, it is offset by higher levels of nominal Gross Domestic Product (GDP), which is the driving factor that tends to stabilize the ratio of government debt to GDP once the fiscal emergency that prompted the debt increases has ended (IMF, 2014).

Monetary Policy: A research conducted by Kraay (2012) in India founded that requirements of economic stabilization and development should be the main guiding forces that are used by the monetary authorities in determining the supply of money and interest rates in a developing nation rather than inflation targets that have been adopted by many developing countries. With regards to exchange rate policy, most scholars are of the opinion that developing countries in Asia, Latin America and Africa should select appropriate exchange rate regimes (free or managed Floating and fixed exchange rate systems) taking into account the competitiveness of exports as well as potential of attracting speculative attacks. Looking at the control of the external account, the World Bank (2013) suggested that developing countries should act cautiously in liberalizing their capital account and carefully consider the impact of tariffs on goods and services. Available statistics from most studies suggest that most emerging nations including Brazil, Russia, India, China and South Africa have adopted inflation targeting as their main, if not as one of their monetary policy objectives during the past few decades. Whereas the World Bank (2012) also founded that since the early 90s, many developing nation's monetary objectives have been shifted away from targeting money supply towards inflation targeting. However, Although inflation targeting has a well-known record of success in many developed and developing countries over the past few decades (IMF, 2012), Kraay (2012) paper shows that Inflation targeting has not achieved the expected results in many other developing countries especially in Africa where poverty prevails.

In explaining the failure of inflation targeting, the IMF (2014) paper ascertain that there are several requirements which are vital in determining the success (or failure) of inflation targeting as the main objective of monetary policy which might not be present in some countries. These prerequisites include a flexible exchange rate regime as well as full commitment to price stability (IMF, 2012). However, economists 
have argued in the past decade that the requirements provided by IMF are simply starting points and are not sufficient for inflation targeting regime to succeed. No doubt, basic economic theory suggest that the most vital requirements for inflation targeting to succeed is a sound financial system and a reliable economic data for making credible forecasts. On the other hand, available statistics show that the failure of inflation targeting in some of the developing nations in Latin America was largely due to a lack of transparency of monetary policy and policy transmission. There is therefore no doubt, that opening a country's capital account in a sequenced pattern is important as well as accruing exchange reserves and achieving current account surplus or low deficit and argues that China is a perfect example. Furthermore, there is an on-going debate that other BRICS countries can learn a lot from China with regard to monetary policy issues. For example, huge central bank interventions and sterilization to preserve surpluses in the current account is one the major lessons that Brazil, India, Russia and South Africa can learn from China but did not clearly explain the exact central bank interventions the author referred to. On the other hand, huge central bank interventions need massive amounts of foreign reserves of which some developing countries may not have especially with regard to the unpredictable exchange rate oscillations.

Capital account opening, stable monetary and exchange rate regime, flexible labour markets, anti-corruption, sustainable balance of payments, reduced budget deficits to non-inflationary levels are some of the main policy endorsements for developing nations in their search of a sustained economic trajectory. In addition, Most of these recommendations are part of those prescribed by the Washington Consensus (2003) and to a certain extent, supported by International Monetary Fund (IMF), World Trade Organisation (WTO) and World Bank. The policies of these institutions to a very a large extent, are the main policies that many developing countries including Brazil and South Africa have adopted for more than two decades. However, these recommendations are not sufficient without other fiscal buffers for developing countries; rather we do recommend that other nations should learn from China and other Asian countries. Thus, most countries that embraced the IMF and World Bank policy prescriptions did not achieve minimum targets due to the 2008 world-wide financial crisis including some of the BRICS countries namely, Brazil, Russia and South Africa (Nassif et al., 2015).

Fiscal Policy: The basic tenants' of fiscal policy is the state's ability to use taxation to generate revenue and its expenditure in order to influence the aggregate level of economic activity and also to affect income distribution as well as the allocation of resources in the economy. In addition, IMF (2015) states that fiscal policy should promote economic growth with the use of macro and structural tax systems and expenditure policies. Various researchers and economists suggested that government expenditure should be increased on research and development, infrastructure and education especially in productive economies. Investing in human resources is greatly supported by the United Nations Economic Commission for Africa (2015). Skilled labour shortage issue in South Africa and other African nations can be addressed by increasing spending on education structures. In addition, the UN Economic Commission (2015) states that one of the major lessons that African countries (including South Africa) and other developing nations can learn from the success of East Asian countries (including China) is that Africans need to shift their traditional resource endowment and comparative advantages towards skilled and knowledge based structure by investing heavily on human resources. Therefore, government expenditure can play a vital role in the improvement of workforce skills.

On the Taxation side, The Davis Tax Commission (2014) argues that the issue of inequality which is a major challenge in Brazil and South Africa can be addressed by using a taxation system that is progressive with both vertical and horizontal equity. For instance, Individuals that earn lower income should pay a tax amount that is less than the amount paid by someone who earns higher income meaning it should be progressive. However, empirical evidence suggests that tax evasion in Russia is one of the major problems and corruption is high especially among government officials. Thus, in order to increase government tax revenue in Russia, the tax collection systems need to be enhanced. In Brazil, tax on the value of goods and services (VAT) is used as one of the major sources of government revenue although the VAT is famous for being regressive (IMF, 2013). The VAT is regressive in this context due to the fact that poor people might end up paying more VAT due to their expenditure patterns. In South Africa, Khamfula (2011) suggested that one fiscal solution that South Africa can implement in order to attract more foreign firms is to offer foreign investors substantial tax holidays or tax cuts. With regard to the issue of corruption, a study conducted by Rodrik (2003) founded that corruption has a strong positive relationship with growth in GDP per capita growth in China. This was also 
supported by a comparative study conducted by OECD on sustainable governance indicators within BRICS which founded that China did not only lead in increasing GDP growth rates among BRICS countries but also corruption while South Africa performed well in revenue collection. It is highly recommended that developing countries embrace a stable taxation rule and spend where essential to foster development which would protect the poor. Hence, the general impact of taxation and expenditure policies must be progressive.

\section{Content Analysis: BRICS countries}

Monetary policy-Monetary policy and monetary instruments within BRICS: The BRICS economies work under different monetary policy systems. Brazil and South Africa have different inflation targets while china, India and Russia use multiple monetary target systems (BRICS report, 2014). The Brazilian monetary policy in the 2000s was always rooted in central bank's inflation targeting while maintaining a very dirty floating exchange rate regime and target for a substantial primary budget surplus (Weisbrot, Johnston and Lefebvre 2014, p.10). Brazil's monetary authorities implemented official inflation point target of 4.5 per cent in June 1999 (IMF, 2014). The point targeted inflation rate was reduced to 4 per cent in 2001 and 3.5 per cent in 2003 (World Bank, 2014). The main monetary policy instrument in Brazil is the overnight interbank interest rate also known as the Over-Selic rate. Open market operations are also used in Brazil but are the primary duty of Open Market Operations Department which is well known by the Acronym Demab. On the other side, the maintenance of financial stability and creation of conditions that are required to achieve sustainable economic growth are the main goals of Russia's monetary policy (BRICS report, 2014). However, Owen and Robinson (2003) argue that in the early 2000s, the monetary policy in Russia was directed towards controlling the inflation rate and also smoothing the fluctuations of the exchange rate. For instance, after the production collapsed in the late 1990s and the Russian 1998 crisis, the central bank acted quickly to solve the problems in the banking industry and also tried to quickly enhance the payment system. From 2012, the primary objective of the Russian central bank was to decline inflation to 5 per cent annual average (IMF, 2014). Open market operations (are used to affect interest rates); standing facilities and reserve requirements are the main monetary instruments that are used by the Bank of Russia (BRICS report, 2014). This is in accordance with the GAIDAR REPORT (2014).on Russian economy.

The main objectives of the Indian monetary authorities are to maintain price stability, promote the flow of credit towards the productive sectors and achieve more inclusive economic growth (World Bank, 2014). However, International Financial Statistics paper published for the International Monetary Fund in (2010) states that monetary policy in India evolved with the rising current and capital account liberalisation, financial sector liberalisation and changing patterns of credit requirements (IMF, 2014). In addition, India adopted a multiple approach strategy in 1998 and growth in money supply is primarily used as an indicator of monetary policy measures. Central bank of India introduced a liquid adjustment facility in order to facilitate short term liquidity and provide a clear signal of short term interest rates that may be consistent with policy objectives (BRICS report, 2014). The reserve bank of India currently uses a combination of large market borrowings (sales of bonds and other securities) and strategic open market operations. China also uses a multiple approach strategy as its monetary framework. Wang and Handa (2007) state that, during the period 1993-2003, the People's Bank of China Adjusted the interest rates with the aim of targeting inflation and smoothing output. From 2004, the goal of the monetary authorities in China is to sustain the stability of its currency value without discouraging economic growth (IMF, 2014). The monetary policy instruments used by the People's Bank of China (PBC) include the reserve requirement ratio, central bank base interest rate, rediscounting, central bank lending, open market operations, and other policy instruments specified by its State Council (BRICS report, 2014). The monetary policy committee in China advises the People's Bank of China in the formulation and adjustment of monetary strategies through its various monetary instruments. In addition, the committee also provides advice on monetary policy targets for a certain period as well as application of monetary instruments (BRICS report, 2012).

The main duty of the South African monetary authority commonly known as the South African Reserve Bank (SARB) is written in the country's constitution as the protection of the value of its currency with the main interest of achieving balanced and sustained growth in the nation (BRICS statistical report, 2015). However, the official inflation target range of 3 to 6 per cent was announced in February 2000 by its minister of finance (National Treasury, 2012). Prior to that, Khamfula (2011, p.15) explain that the path to long term economic 
growth was targeted by introducing macroeconomic policies aimed at reducing fiscal deficits, decreasing inflation, promoting exchange rate stability, declining barriers to trade as well as liberalising capital flows which are similar Washington Consensus policy recommendations. The South African Reserve Bank uses repo rate adjustments, open market operations and reserve requirement as its monetary instruments. The adjustments in the interest rates are mostly used to achieve the targeted inflation interval (SARB, 2014). The discussions on monetary policy objectives of BRICS reflect that these countries have a shared interest in price stabilization through some form of inflation targeting. Russia has made several changes with regard to the objective of its monetary goals while Brazil has decreased its point targeted inflation rate. The main concern of SARB has been to maintain inflation rate within its target range of 3 to 6 per cent while Chinese monetary authority sometimes uses interest rates to indirectly affect prices within the country. In India, interest rates are used to reflect the prospective objective of monetary policy and credit creation measures are signalled using the interest rates.

Exchange rate policy and financial accounts within BRICS: Brazil is known as one of the nations that have followed some of the macroeconomic strategies that are part of the Washington consensus (Fisher, 2001). These strategies include (but not only) liberalisation of trade, promotion of foreign direct investment, deregulating domestic financial markets and trade as well as price stability. The pegged exchange rate regime which was used in Brazil during the early 1990s resulted in a decline in the value of its currency and made imports more expensive (Frenkel, 2006). Currency crisis in Brazil was experienced in 1999, which led the country to adopt a floating exchange rate regime together with inflation targeting (IMF, 2006). Further declines in the regulations of financial markets were also experienced which mainly focused on decreasing the restrictions on foreign investor's participation in security markets (de Paula, 2012). Output drop in Russia was experienced during the 90s mainly due to the transformation of the economy from a command to a market economy (IMF, 2012). This was reflected by the privatisation of public firms, quick process of financial and trade liberalisation (de Paula, 2012). At that time, monetary policy authorities had to decrease the ballooning inflation rate which was 300 per cent in 1994 (de Paula, 2012). In addition, the exchange rate was kept pledged within a corridor (de Paula, 2012). After the 1998 crisis, Russia adopted a floating exchange rate regime that is administered by the relevant authorities in the context of capital account that is partly convertible (IMF, 2014). The objective was to obtain foreign reserves that will assist in preventing the rapid growth in exchange rate and maintaining it to manageable levels. Arezki et al. (2012) also supports these findings.

The IMF (2001) founded that the period from 1991 to 1997 in India reflected a period of dramatic liberalisation of trade. At the same time, the exchange rate regime in India was also shifted from being pegged to more of a controlled floating exchange rate (de Paulo, 2012). The flexible exchange rate system in India is also supported by the role that the reserve bank of India plays in the exchange rate market (IMF, 2014). This role includes the avoidance of huge transactions that would raise the volatility of the Indian currency. The IMF (2014) research publication also adds that the reserve bank of India also participates in the spot markets as well as in the market for derivatives. On the other hand, volatility of the exchange rate in India is relatively lower when compare to its counterparts that also adopted the floating exchange rate system (de Paulo, 2012). The Indian real exchange rate has been relatively stable however, the nominal exchange rate has devaluated. de Paulo (2012) further argues that interest rates in India have been sometimes used to affect the exchange rate and this has sometimes resulted to unpredicted swings in domestic interest rates.

Various researchers including IMF (2012) state that during 1985 and 1993, China had a floating exchange rate and that foreign direct investment was greatly encouraged. The official adoption of a managed exchange rate system was adopted in 1994 in china (de Paulo, 2012, p.15). However, some evidence of a fixed currency regime is shown by de Paulo in his research article published in 2002. The aims of the exchange rate systems adopted in china are also argued to have varied throughout different time periods but mostly aimed to maintain the independency of its monetary authorities, encouraging firms to avoid too much international risk, sustaining current and financial account equilibrium and promoting a stable exchange rate (IMF, 2012). On the other hand, the country also maintained control on exchange rates transactions with the aim of trying to avoid being damaged by the international financial crises. Sometimes citizens were encouraged not to take part in the money, derivative and stock market but could only purchase certain amount of shares. 
South Africa has an uncontrolled exchange rate system also known as a floating exchange rate (SARB, 2016). Although the floating exchange rate is assumed to be determined by the demand and supply in theory, the South African reserve bank has played a part by purchasing and selling other currencies in the exchange rate market (IMF, 2014). The floating exchange rate system was first adopted in the 1980s and 1990s in South Africa whereby the monetary authorities of the country addressed stabilising measures in the country's exchange rate market (Van der Merwe, 1996). During the period from 1985 to 1995, a dual exchange rate system was used which involved a free floating exchange and a managed floating exchange rate (Mtonga, 2011, P.04). Mtonga (2011, P.04) also states that a managed floating exchange rate system was adopted in 1995 till 2000 and since then a free floating exchange rate regime (with inflation interval being targeted) has been adopted. The exchange rate in South Africa has mostly depreciated after inflation targeting was adopted in 2000 (IMF, 2014).

Fiscal policy: Fiscal plan is generally about the state's ability to use taxation to produce revenue and it's spending in order to impact the aggregate level of economic activity and also to effect income spreading as well as the sharing of resources in the economy. In addition, fiscal activity can be measured by observing at a country's government deficits, borrowings, taxes and its expenditure. As in many other countries, fiscal policy has also been another policy concern in the BRICS members and many other countries have been challenged with increasing fiscal deficits as well as public debt (IMF, 2014). This reflects that government revenue has not been enough to cover government expenditure in many developing countries. The BRICS summit held in Toronto in 2010 resulted in BRICS leaders agreeing to adopt responsible economic strategies, declining fiscal deficits and preventing the ever rising public debt of the respective governments (BRICS report, 2014). However, if the budget deficits are to be decreased by all BRICS members, it theoretically means revenue has to increase or expenditure must decline. Hence, one cannot change one fiscal variable without considering the impact it might have on the other (trade-off). Tax reforms have generally been driven by the need to provide a fiscal environment that is more conducive to investment, risk-taking and work incentives, while also improving the fairness, simplicity and transparency of the tax systems (OECD, 2007).

Gross Dept to GDP ratio within BRICS: Government borrowing is widely accepted as a key fiscal component in economic theory and practice especially since government's revenue seems to be inadequate to finance its expenditure. In fact, government borrowing is a worldwide fiscal consideration in that even the well developed and under-developed economies may use it to finance their expenditure (BRICS Report, 2014).The BRICS Nations are no exception with regards to net borrowing countries. In 2000, gross debt of general government (as GDP percentage) of Brazil was 66.7 per cent and slightly declined to 66.1 per cent in 2010 (International Monetary Fund, 2014). This is way above the general government debt of 40 per cent of GDP as suggested by the New Labours Approach. During the same period, gross debt to GDP percentage of Russia greatly declined from 59.9 per cent in 2000 to only, 9.9 per cent in 2010 while in India it was 71.4 per cent in 2000 and fluctuated till it was 69.2 per cent in 2010. On the other hand, the gross debt to GDP of the Chinese government was 16.4 per cent in 2000 and slightly increased to 17.7 per cent in 2010. In South African government had 42 per cent in 2000 and its debt to GDP ratio declined to 35.7 per cent in 2010 (IMF, 2014). Our contextual analysis is in agreement with the Bricks Report (2012) published by Oxford University Press. The trajectories in both analysis are the fairly the same. These observations show that the BRICS governments are indeed different and follow different steps as far as borrowings are concerned. In fact, most of the BRICS nations have decreased government borrowing since the year 2000 except China. Currently, Russia and China have debts that are way less than 40 per cent of GDP.

Taxes and government revenue: Looking at public revenue, 19 per cent of revenue of the general government of the Russian federation came from company taxes in 2000 and has fluctuated till it decreased to only 9 per cent in 2014 (World Bank, 2014). Income tax of citizens accounted for 8.2 per cent of total government revenue in 2002 and increased to 10.2 per cent in 2014 (BRICS statistical report, 2015). However, de Paula (2012, p.09) states that the state inability to collect taxes is one of the major reasons of the Russian financial problems. On the other hand, 51 per cent of Indian government revenue was from taxes in 2000 and this percentage has increased 61 per cent in 2013 (BRICS statistical report, 2015). However, de Paulo (2012) argues that the liberalisation of Indian capital account was also accompanied by a decline in import taxes. 84 percent of Chinese total revenue came from taxes in 2007 but this percentage has declined to 74 percent as of 2014 (BRICS statistical report, 2015). It is also worth noting that Value added tax was 
adopted in 1994 in china and accounts for more than half of all revenues in Chinese government revenue. However, many scholars have argued that Brazil may be one of the world's most fiscal decentralised nations with sub-national government responsible for collecting taxes. Tax rates are generally viewed as high in Brazil (BRICS statistical report, 2015). Similarly, Tax is the main source of government revenue in South Africa (National Treasury, 2014). However, income tax in the country plays a role in addressing the problem of inequality in that those who earn higher incomes are taxed more and a proportion of these funds are redistributed to the poor citizens of the country in the form of social grants systems. South Africa Revenue Services commonly known as SARS collects all taxes centrally,

The fiscal policies adopted by BRICS nations reflect that all five nations have implemented some measures aiming at decrease their budget deficits especial after the 2008 global financial crisis. Brazilian fiscal authorities committed themselves to trying to maintain a primary budget surplus based on the guidelines that are stipulated every year. At the same time, India also plans to decrease its fiscal deficit. On the other hand, China has showed some relative changes in its budget expenditure which may reflect that a decline signals an attempt to decline deficits and public debt (IMF, 2015). From the 1990s, budgeting in South Africa has been made more transparent by publishing medium run government estimated expenditures over 3 year periods (BRICS report, 2014). Russia has actually taken steps to decrease its fiscal deficits, shown by a sharp decline in public spending over Gross domestic product ratio (BRICS Statistical report, 2015).

Economic outcomes of Macroeconomic policies within BRICS: A review of Brazil's macroeconomic trajectory performance from 2002 to 2012 suggests a huge impact on the reduction of poverty and inequality. Despite being extremely unequal, Brazil has reduced inequality the most over the past two decades (World Bank, 2015). Taxes are widely accepted as one of the strategies that countries can use to decrease income inequality. However, the introduction of Bolsa familiacash transfers from government to the poor citizens in 2003 have been adjudged by many as contributing greatly to the reduction of poverty in Brazil, but also created excessive demand for goods and services which might be the reason Brazil has been battling with inflation. Research conducted by the International Monetary Fund suggests that inflation in Brazil is generally demand driven as stated in standard macroeconomics theory and can be corrected with macroeconomic policies. On the other hand, India has since independence been a traditional mixed emerging economy with substantial private sector participation. Federal State Statistics Service (2015) is in agreement that fiscal policy in India have been planned and executed in framework alike to those of other capitalist economies where unintentional joblessness is high and economic processes have to be used to motivate real demand. However, 1991, is regarded by many economists as the shifting point for India's economy, because of the major policy shift through structural adjustment programs. Policy changes were effected across major sectors, which opened-up the economy for outside involvement in the form of foreign capital and technology.

Available statistics indicate that from 1991 to 1997, China followed a tight fiscal and monetary policy framework. However, between 1985 and 1986, after economic growth reached above 12 percent, China also adopted tight fiscal and monetary policies on account of strong investment inflows. Nonetheless, the later period was the first time the government used fiscal and monetary buffers in macroeconomic-controls. In addition, according to Sala-i-Martin (2002) the government reduced interest rates and expanded money supply at first to revive the economy, but saw a record high inflation rate of 21.7 percent in 1994 . On the other hand, the foremost experience in the Chinese economy during the mid-1990s was that the government implemented policies in order to achieve non-inflation growth. This was achieved by curbing price hikes in the system and this subsequently maintained money supply growth and fiscal outlays within a moderate range. Nonetheless, Chinese economy did experience rapid economic growth with massive government intervention and currently has socialist democratic political system (United Nations, 2015). The most obvious symptom of Russia's economy is high inflation (World Bank, 2009). In addition, the Russian ministry of finance argued that the long lived decline in Russia's output is hardly due to a lack of monetary and fiscal policy measures. For instance, a firm that would be profitable in free markets face severe capital market constraints and heavy taxation in Russia. In addition, Dollar and Kraay (2002) argue that firms in Russia face great difficulty in borrowing to finance working capital ever since the early 90s. Nonetheless, ever since the fall of Old Soviet Block, most of Russian macroeconomic policy frameworks have been directed towards the sale of state owned enterprises and participation in the Global markets. 
South Africa has continued to manage public finances in a counter cyclical manner to support long-run fiscal sustainability (South African Reserve bank, 2014). The contraction of the combined government balance has been sustained over the medium-term spending framework. This has been done through a control in the growing of expenditure and a recovery in revenue in line with the economic cycle (The BRICS report, 2014). The public sector has been used to sustain large-scale infrastructure projects to address transportation, water, and energy sector bottlenecks. Social income awards provide a safety net for the poor, while initiatives to support job creation have been intensified (the BRICS report 2014). South Africa's investment proportion has increased strongly over the past decade as government and public corporations have stepped up infrastructure investment, but overall asset outlay is constrained by low reserves (BRICS statistical report, 2015).

\section{Conclusion and Recommendations}

This paper aimed to provide a comparative analysis of macroeconomic policies adopted by the BRICS countries for the past fifteen years. Based on the research presented, it is clear that the BRICS countries have some form of inflation targets as the objective of their respective monetary policy. In addition, the article also showed that since the year 2000, all the BRICS countries have a floating exchange rate regime with some central bank participating in the Foreign Exchange Market in order to protect the value of the currency. On the Fiscal Side, the research presented has showed that all the BRICS governments have taken several steps to decreasing government borrowing and deficits especially after the 2008 Global crisis. In addition, Tax collection schemes seem to have improved in Russia and China although tax evasion is still a major challenge. Based on the results, Brazil, China and South Africa rely heavily on taxes for generating government revenue and China has taken some steps to find other sources of income.

Although the BRICS countries have performed well with using their monetary and fiscal policy, the seems to be some existing domestic, social and economic problems such as corruption, poverty, inequalities, absence of proper health care and educational facilities to mention a few. These are some of the issues that can be dealt with using both fiscal and monetary policies. Specifically, the following polices are recommended for the BRICS:

- It therefore follows that the BRICS countries should align the two policy regimes because of current macro challenges. Each of the regimes should be tailored to address a specific problem especially where it concerns structural impediments. An interesting move seems to be happening at the international space to the disadvantage of some of the BRICS countries. Thus, addressing systemic and structural deficiencies would be a step in the right direction for the BRICS. This will positively influence structural deficiencies neglected in the past. A realignment of fiscal regimes is considered necessary for the BRICS in terms of increasing their tax base instead of cutting social expenditure. Howbeit, a reallocation of government expenditure from current to capital expenditure would provide opportunity for tackling structural deficiencies

- South Africa in particular needs to change the unsupportive international climate as wells address domestic challenges. This could be achieved by a stricter management of public debt by member countries of BRICS. A further increase in the trend could lead to a credit rating downgrade to junk status, which would hurt the economies of the BRICS members.

- Monetary policy should lean towards being accommodating to partially compensate for a contractionary fiscal policy for the BRICS, which would stabilize government finances in the short and medium term.

Pockets of inequality and poverty are obvious among the member countries. It has therefore become imperative that an inclusive economic agenda be adopted across board to tackle unemployment and poverty. This wills positively impact on social inclusion. Lending for infrastructure development purposes need to be encouraged within the BRICS partnership by promoting the objectives of the BRICS bank in order to assist some of the BRICS members. There needs to be a development of proper channels that aim to deal specifically with the conflicts or disputes that may arise within the BRICS country in the future. Also, these channels might assist in protecting vital information from leaking into the hands of international speculators that can harm the growth prospects of the BRICS. All BRICS members should be encouraged and supported by other 
partners to promote and maintain economic stability. The rural/urban disparities within each BRICS country need to be addressed by partnering with private sector. There is therefore a need for effective participation of citizens of member countries in the public discourse, role and debate of the role of BRICS within the international arena. This will further highlight the contemporary issues and opportunities for each member country.

\section{Reference}

Arezki, R., Dumitrescu, E., Freytag, A. \& Quintyn M. (2012). Commodity Prices and Exchange Rate Volatility: Lessons from South Africa's Capital Account Liberalization. IMF Working Paper WP/12/168. Washington, D.C.: International Monetary Fund.

Bernheim. (1987). Ricardian Equivalence: An Evaluation of Theory and Evidence. NBER Macroeconomics Annual, 2, 263-316.

BRICS Statistical Report. (2014). Research on the Economic and Trade Cooperation Mechanism among BRICs. Beijing: China Financial and Economic Press.

BRICS Statistical Report. (2012). BRICS and the challenges of fighting inequality. BRICS policy firm. Brazil

BRICS Report. (2012). A Study of Brazil, Russia, India, China, and South Africa with special focus on synergies and complementarities; Oxford University Press BRICS Statistical Report. (2015)

Dollar, D. \& Kraay, A. (2002). Growth is good for the poor. Journal of Economic Growth, 7(3), 195-225.

de Paulo, F. (2012). Financial liberalisation, exchange rate regime and economic performance in BRICs Countries. JEL classifications. Brazilia.

Fischer, S. (2001). Exchange rate regimes: Is the bipolar view correct? Journal of economic perspectives, 15(2), 3-24.

Frenkel, R. (2006). An alternative to in inflation targeting in Latin America: macroeconomic policies focused on employment. Journal of post Keynesian Economiucs, 28(4), 568-598

Gaidar Report. (2014). Russian Economy in 2013: Trends and Outlooks, Issue 35: Industrial Policy in Russia in 2000-2013: Institutional Features and Key Lessons, Section 6: 395-428, Moscow: Gaidar Institute for Economic Policy. 38

Goldman, S. (2003, P.05). Brics and Beyond, Goldman Sachs Global Economic Research,

Herr, H. \& Priewe, J. (2005). Beyond the Washington consensus: Macroeconomic policies for development

IMF. (2006). Annual reports on exchange arrangements and exchange restrictions. International monetary fund. Washington D.C

IMF, (2014). Annual reports. Washington D.C

Khamfula, K. (2011). Elite Transition: From Apartheid to Neoliberalism in South Africa (London: Pluto Press)

Kraay, A. (2004). When Is Growth Pro-Poor? Cross-Country Evidence, IMF Working Paper, WP/04/47

Kraay, A. (2012). Government Spending Multipliers in Developing Countries: Evidence from Lending by Official Creditors. International Growth Centre Workshop on Fiscal and Monetary Policy in Low-Income Countries, 2-3, 2012.

Mtonga, E. (2011). Did it matter? Monetary Policy Regime change and exchange rate dynamics in South Africa. World Bank group. ( P.04)

Nassif, A., Feijo, C. \& Araujo, E. (2015).Structural Change and Economic Development: is Brazil Catching-up or Falling-Behin? Cambridge Journal of Economics, 39, 1307-1332.

National Treasury website. (2016). New growth path (2014).Emerging economies and policy strategies. University Press.

O’NEILL, J. (2001). Building Better Global Economic BRICs. Goldman Sachs Global Economic Paper No. 66.

Owen, D. \& Robinson, D. (2003). Russia Rebounds. Washington: IMF

Sala-i-Martin, X. (2002). The Disturbing Rise of Global Inequality', National Bureau of Economic Research Working Paper, No. 8904, April.

Van, M. (1996). Exchange Rate policies in South Africa: Recent Experiences and Prospects; Occasional paper No.9, South African Reserve Bank

Wang \& Handa. (2007). Dreaming with BRICs revised: The Path to 2050,' Global Economics Paper No. 99, Goldman Sachs, London, p.2.

Weisbrot, M., Johnston, J. \&Lefebvre, F. (2014). The Brazilian economy in transition: Macroeconomic policy, Labour and inequality. p.10 
World Bank. (2014). The Emergence of China: Opportunities and Challenges for Latin America and the Caribbean. Washington: Inter-American Development Bank.

World Bank. (2011). World Development Report: Conflict, Security, and Development. World Bank, Washington, DC.

World Bank. (2005). Global development finance 2005. Washington D.C

WTO. (2002). Trade Policy Reviews: First Press Release, Secretariat and Government Summaries. India: June 2002. Geneva: World Trade Organization. (https://www.wto.org/english/tratop_e/tpr_e/tp195_ e.htm). Accessed on 29 May 2015. 